\title{
DOMINASI PATRIARKI BERBENTUK KEKERASAN SIMBOLIK TERHADAP PEREMPUAN PADA SINETRON
}

\section{Domination of Patriarchi in the Form of Symbolic Violence on Women in Soap Operas}

\author{
Ghina Novarisa \\ Program Studi Ilmu Komunikasi, Universitas Andalas \\ Kampus Unand Limau Manih, Gedung B Fisip Lt2, Kota Padang, Sumatera Barat
}

Diterima 19 Agustus 2019/ Disetujui 25 September 2019

\begin{abstract}
Violence that is difficult to overcome is symbolic violence because its failure does not look like ordinary struggle. Women are one of the social groups that are the object of symbolic struggle. Media content that supports symbolic making through words and communication that contain hatred against racist backgrounds or that involve sexists to hurt one's personal, ethnic, or sexual coordination.This research explain how symbolic violence operates in the soap opera "Catatan Hati Seorang Istri" by exposing the patriarchal ideology as the dominant ideology in the soap opera. This is a qualitative research with discourse analisys by Sara Millls as the method to analyze the text, and text analysis technique along with literature study to collect the data. The concept of symbolic violence, that is used in this research, assumes that domination by men against women produce symbolic violence. The result of this research indicates "Catatan Hati Seorang Istri" showing domination of men over women in the form of (1) domination on behaelf of obligation in domestic territory, (2) domination by putting women as sexual object, and (3) domination by silencing women. But, those form of domination causing women to fight against their rights.

Key words; Symbolic violence; dominance; patriarchi ideology; soap operas.
\end{abstract}

\begin{abstract}
ABSTRAK
Kekerasan yang sulit diatasi adalah kekerasan simbolik karena dampaknya tidak terlihat seperti kekerasan biasa. Perempuan adalah salah satu kelompok sosial yang menjadi objek kekerasan simbolik. Konten media seringkali memproduksi kekerasan simbolik melalui kata-kata dan komunikasi yang mengandung kebencian dengan latar belakang rasis atau yang bersifat seksis bertujuan melukai integritas pribadi, etnis, atau seksual seseorang. Penelitian ini membahas bagaimana kekerasan simbolik beroperasi dalam sinetron Catatan Hati Seorang Istri dengan membongkar ideologi patriarki sebagai ideologi dominan dalam sinetron tersebut. Penelitian ini merupakan penelitian kualitatif dengan metode analisis wacana Sara Mills dan teknik pengumpulan data melalui analisis teks, serta studi literatur. Konsep kekerasan simbolik yang digunakan dalam penelitian ini adalah bagaimana dominasi yang dilakukan laki-laki terhadap perempuan melahirkan kekerasan simbolik. Hasil penelitian ini menunjukkan bahwa sinetron Catatan Hati Seorang Istri menampilkan dominasi laki-laki terhadap perempuan dalam bentuk; (1) dominasi mengatasnamakan kewajiban wilayah domestik, (2) dominasi menempatkan perempuan sebagai objek seksual, dan (3) dominasi dengan membungkam perempuan. Namun, bentuk dominasi tersebut membuat perempuan memberontak dan bersuara. Dominasi inilah yang mendasari kekerasan simbolik pada sinetron Catatan Hati Seorang Istri.
\end{abstract}

Kata Kunci ; Kekerasan Simbolik; dominasi; ideologi patriarki; sinetron.

\footnotetext{
*Korespondensi Penulis

Email: ghinanovarisa90@gmail.com
} 


\section{PENDAHULUAN}

S.Jehel (2003) dalam dalam Haryatmoko, (2010) menyatakan logika kekerasan merupakan logika kematian karena bisa melukai tubuh, melukai secara psikologis, merugikan dan bisa menjadi ancaman setiap integritas pribadi. Haryatmoko menambahkan, kekerasan tidak harus dalam bentuk fisik namun bisa menghancurkan dasar kehidupan seseorang. Kekerasan yang sulit diatasi adalah kekerasan simbolik karena dampaknya tidak terlihat seperti kekerasan biasa. Oleh karena itu, penelitian ini penting untuk menguraikan bentuk-bentuk kekerasan simbolik beroperasi.

Konten media seringkali
memproduksi kekerasan simbolik melalui kata-kata dan komunikasi yang mengandung kebencian dengan latar belakang rasis atau yang bersifat seksis bertujuan melukai integritas pribadi, etnis, atau seksual seseorang (Heitmeyer, Wilhelm dan Hagan, 2005). Bourdieu (1991) mendefenisikan kekerasan simbolik sebagai kekerasan yang tidak tampak. Kekerasan simbolik terjadi ketika adanya keterlibatan orang-orang yang tidak ingin tahu bahwa mereka merupakan sasaran dan mereka menjalankannya setiap hari. Ia menambahkan bahwa kekerasan simbolik merupakan kekerasan yang lunak, dipraktikan dalam kehidupan sehari-hari secara repetitive (Dwizatmiko, 2010).

Erzgraber dan Hirsch (2001) dalam Heitmeyer, Wilhelm dan Hagan (2005) menekankan bahwa pada dasarnya kekerasan simbolik dapat dipahami sebagai ekspresi budaya. Mereka mencontohkan kekerasan simbolik dalam bentuk bahasa menempatkan kekerasan sebagai tindakan mental seperti meneriakkan, menganiaya, menyinggung, memfitnah, mencemarkan nama baik, mendiskreditkan, meremehkan, membodohbodohi, merendahkan, mengacuhkan, atau mempermalukan seseorang, termasuk juga penghinaan dan pembunuhan karakter.

Kekerasan simbolik tidak terjadi pada tingkat individu saja. Kekerasan simbolik juga dapat berupa mendeskriditkan kelompok atau golongan marginal yang tidak memiliki kekuasaan atau subordinat. Perempuan adalah salah satu kelompok sosial yang menjadi objek kekerasan simbolik. Kekerasan simbolik terhadap perempuan berupa praktik memarginalkan, mensubordinatkan dan memberikan label negative terhadap perempuan (Dayanti, 2006). Media memproduksi berbagai narasi untuk memperkuat dan melanggengkan stereotipe tentang perempuan. Televisi juga turut melanggengkan diskriminasi terhadap perempuan.

Dominasi laki-laki terhadap perempuan merupakan dasar dari kekerasan simbolik, sebuah bentuk kekerasan yang sangat halus, tidak terlihat dan tidak disadari. Tokoh perempuan sebagai objek kekerasan simbolik tidak terlepas dari latar belakang budaya patriarki (Bourdieu, 2001). Wacana patriarki merupakan kekerasan karena menjebak perempuan dengan menentukan cara melihat, merasakan, berpikir, dan bertindak (Haryatmoko, 2010). Lerner (1986) dalam Rakoczy (2004) menambahkan dari dulu hingga sekarang masyarakat mengadopsi norma-norma patriarki dalam setiap aspek masyarakat dan telah menjadi cara hidup'. Maka dari itu, sistem patriarki terkonstruksi menjadi sebuah hal yang wajar dan biasa. Patriarki berarti "kekuasaan ayah", dimana perempuan berada dalam dominasi laki-laki.

(Bretthauer, Zimmerman, \& Banning, 2007) dalam penelitiannya menyatakan Kekuasaan atas, objektifikasi, dan kekerasan terhadap perempuan adalah kerangka muncul dalam lirik musik. Dalam kerangka ini, enam tema diidentifikasi: lakilaki dan kekuasaan, seks sebagai prioritas utama laki-laki, objektifikasi perempuan, kekerasan seksual, perempuan didefinisikan dengan memiliki laki-laki, dan perempuan tidak menghargai diri mereka sendiri. Tematema ini mengirimkan pesan gender dan hubungan ke pendengar musik, yang sebagian besar adalah remaja.

Penelitian lain dari (Sobari, 2011) menyatakan kekerasan simbolik dicerminkan dalam lagu lagu dari grup band the changcuter, terutama terjadinya marginalisasi objek perempuan. Laki-laki menggambarkan dominasi yang kuat dalam bentuk kekuasaan patriarki dalam memberikan citra buruk perempuan. Teks lagu, dalam konteks ini, dijadikan propaganda bagi pembangunan buruk karakter perempuan. Melalui analisis wacana, diketahui bahwa lirik lagu grup the 
changcuter telah melakukan kekerasan simbolik dengan menempatkan perempuan sebagai racun dunia, pemimpi laki-laki, dan buruan laki-laki. Penggambaran perempuan pada posisi ini secara simbolik melahirkan kesenjangan pemahaman pada satu sisi dan pada sisi lain ideologi lagu grup band the changcuter menempatkan perempuan sebagai objek seks semata.

(Alnashava, 2012) menemukan representasi kekerasan simbolik terhadap perempuan yang mengkonstruksi ideologi patriarki dalam serial TV di Amerika. Dalam konteks Indonesia, sinetron adalah tayangan televisi yang kerap melakukan pemarjinalan terhadap perempuan. Sinetron adalah agen pembelajaran sosial yang mengkonstruksi dan membentuk sikap, nilai, perilaku dan persepsi khalayak, terutama mengenai realitas sosial. Penelitiannya menemukan sinetron memiliki peran dalam mengkonstruksi realitas perempuan setiap hari dengan menampilkan narasi potret perempuan tersubordinasi atau perempuan sebagai objek melalui bahasa dan gambar (Udasmoro, 2013).

Sinetron adalah salah satu program televisi yang paling banyak dikonsumsi oleh masyarakat Indonesia. Berdasarkan pantauan lembaga survey ACNielson selama tahun 2013 dan tahun 2014, setiap harinya sinentron tidak pernah keluar dari 20 deretan teratas yang mendapatkan rating tertinggi. Dimana rata-rata setiap harinya TVR sinetron mencapai 6,5 dengan share diatas 25
(Ariana Nilesen,2014). Pada 2014, sinetron yang paling sering menduduki puncak rating sinetron adalah Catatan Hati Seorang Istri. Uda (2014) dalam Tabloid online Nova memberitakan sinetron ini sempat memuncaki data kepemirsaan Nielsen Market ABC dengan rating 7,0 dan share 32,2 pada Sabtu, 28 Juni 2014. Berdasarkan data tersebut, sinetron Catatan Hati Seorang Istri merupakan sinetron yang paling banyak di tonton oleh masyarakat pada saat itu.

Tingginya konsumsi sinetron mengakibatkan sinetron sangat bergantung pada tema dan setting sosial yang dibangun atas "permintaan pasar". Sinetron tidak lain adalah soap opera yang dalam sejarahnya menampilkan narasi berorientasikan perempuan. Perempuan adalah objek utama yang menarik untuk ditampilkan. Tematemanya pada umumnya fokus pada kehidupan perempuan. Perempuan selalu menjadi topik utama yang mengalami masalah kehidupan yang berat (dalam (Hamid, Farid dan Budianto, 2011). Terkait dengan hal tersebut, Catatan Hati Seorang Istri adalah sinetron yang menampikan perempuan dari berbagai sudut pandang. Tokoh utamanya adalah Hana dengan dua sahabatnya Vina dan Anisa. Dalam sinopsisnya, fokus ceritanya menggambarkan bagaimana Hana dan dua temannya tersebut sebagai perempuan, ibu, dan istri menyelesaikan permasalahan mereka.

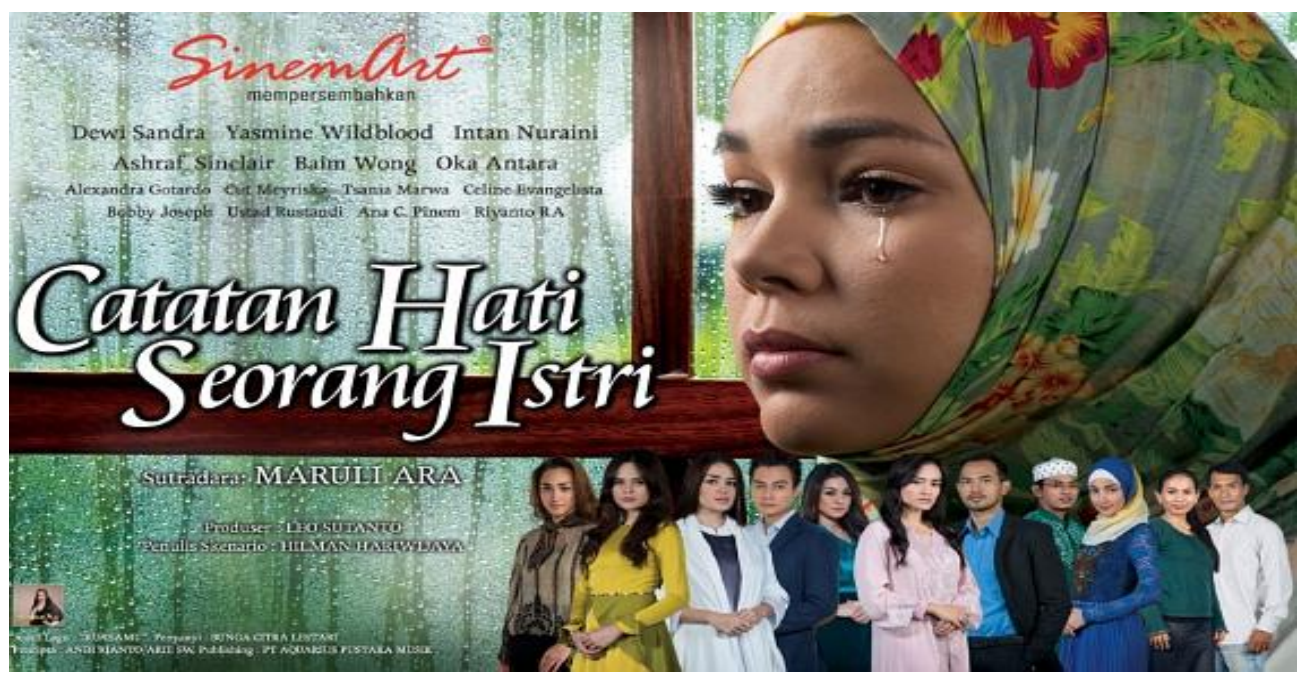

Gambar 1. Poster Catatan Hati Seorang Istri Sumber : wowkeren.com 
Penggambaran tokoh perempuan dalam media massa dianggap sebagai realitas sosial. Realitas perempuan dapat dikonstruksikan melalui penokohan. (Rohimi, 2012) mendeskripsikan tokoh perempuan dalam film sering mendapatkan peran sebagai tokoh utama yang digambarkan memiliki karakter lemah, cengeng, mengalah, dan tertindas. Perempuan sangat mendapat'tempat' namun juga sangat 'ditempatkan'. Perempuan sebagai tokoh utama yang sekaligus juga sebagai objek utama. Penokohan perempuan sebagai tokoh sentral yang diutamakan namun juga objek kekerasan simbolik yang utama. Sinetron Catatan Hati Seorang Istri menampilkan tokoh-tokoh perempuan menghadapi permasalahan rumah tangga mereka mendapatkan apresiasi dari penontonnya. Peneliti menemukan hal tersebut berdasarkan komentar-komentar penonton dalam kelompok diskusi sinetron dimedia sosial dan komentar-komentar yang terdapat dalam running text selama sinetron tersebut tayang. Bagi penonton, tokoh- tokoh dalam sinetron Catatan Hati Seorang Istri adalah cerminan realitas sebagian perempuan di dunia nyata.

Berdasarkan uraian diatas, sinetron Catatan Hati Seorang Istri merupakan sinetron yang laris pada tahun 2014. Sinetron ini memiliki tema perempuan yang merepresentasikan kehidupan perempuan. Representasi perempuan melalui tokoh-tokoh perempuan dalam sinetron tersebut dianggap sebagai realitas oleh para penontonnya. Halhal tersebutlah yang menarik perhatian peneliti memilih sinetron Catatan Hati Seorang Istri sebagai objek penelitian.

Kekerasan simbolik terhadap perempuan di media massa dapat dilihat pada penggambaran perempuan dalam sinetron. Terkait dengan penelitian ini, kekerasan simbolik dalam sinetron ditampilkan melalui penokohan perempuan. Penokohan adalah cara pengarang menggambarkan atau melukiskan tokoh dalam cerita yang ditulisnya. Dalam penokohan, karakter seorang tokoh dapat dilihat dari tiga segi, yaitu melalui: dialog tokoh, penjelasan tokoh dan penggambaran fisik (Nurgiyantoro, 2010).

Untuk meneliti bagaimana kekerasan simbolik beroperasi pada sinetron melalui penokohan, penelitian ini menggunakan pisau analisis analisis wacana Sara Mills. Konsep analisis wacana Sara Mills yang bertujuan membongkar ideology. Titik perhatian konsep ini adalah pada wacana mengenai feminisme. Pandangan feminis berusaha untuk melawan suatu bentuk kekuasaan patriarki. Penggambaran yang buruk dan ketidakadilan mengenai perempuan merupakan sasaran dari tulisan Sara Mills (Eriyanto, 2001). Analisis Sara Mills lebih melihat pada bagaimana posisiposisi actor ditampilkan dalam teks lebih memperhatikan konteks yang lebih luas dan struktur narasi teks. Melalui struktur dan narasi teks, Mills menganalisis berdasarkan kerangka cerita berdasarkan empat aspek yaitu; karakter, fragmentation, focalizations, dan schemata (Eriyanto, 2001).

Berdasarkan rumusan permasalahan penelitian yang telah diuraikan, maka pertanyaan penelitian yang muncul adalah Bagaimanakah konstruksi ideologi patriarki sebagai ideologi dominan yang tersembunyi dibalik penokohan perempuan di dalam sinetron Catatan Hati Seorang Istri. Dan bagaimanakah kekerasan simbolik terhadap perempuan ditampilkan dalam sinetron Catatan Hati Seorang Istri melalui penokohan perempuan. Penelitian ini memiliki tujuan Untuk membongkar konstruksi ideologi patriarki sebagai ideologi dominan dan mengungkapkan kekerasan simbolik terhadap perempuan yang tersembunyi dibalik penokohan perempuan di dalam sinetron.

\section{Kekerasan Simbolik Dalam Sinetron}

Kekerasan ini dikenal dengan kekerasan simbolik yang konsepnya dikembangkan oleh Piere Bourdieu. Kekerasan simbolik merupakan kekerasan yang lunak, dipraktekan dalam kehidupan sehari-hari secara repetitiv. Bourdieu menyatakan "symbolic power is that invisible power which can be exercised only with the complicity of those who do not want to know that they are subject to it or even that they themselves exercise it"'(p.164). Kekerasan simbolik merupakan kekerasan yang tidak tampak, terjadi ketika adanya keterlibatan orang-orang yang tidak ingin tahu bahwa mereka merupakan sasaran dan 
mereka menjalankannya kekerasan tersebut setiap hari (Recuero, 2015).

Kekerasan simbolik tidak lepas dari konsep habitus yang dikemukakan oleh Bourdieu. Habitus mencakup pengetahuan dan pemahan seseorang tentang dunia yang memberikan kontribusi tersendiri pada realitas dunia. Mourkabel (2009) dalam Alnashava, (2012). menyatakan agar kekerasan simbolik bisa bekerja dengan efesien maka kekerasan simbolik membutuhkan habitus yang tertanam untuk bereaksi terhadap kekerasan simbolik tersebut.

Habitus adalah struktur mental atau kognitif yang digunakan aktor untuk menghadapi kehidupan sosialnya. Habitus menggambarkan serangkaian kecenderungan yang mendorong pelaku sosial atau aktor untuk beraksi dan bereaksi dengan cara-cara tertentu (Ritzer, George dan Goodman, 2003). Bourdieu menambahkan habitus merupakan hasil ciptaan (produksi) sejarah dan budaya dari praktik individu-individu (kolektif) dalam kehidupan yang berlansung selama periode historis yang relative panjang. Habitus sebagai produk dari sejarah tersebut, menciptakan tindakan individu dan kolektif dan karenanya sesuai dengan pola yang ditimbulkan oleh sejarah. Kebiasaan individu tertentu diperoleh melalui pengalaman hidupnya kemudian terinternalisasi dalam dirinya, untuk kemudian mereka gunakan untuk merasakan, memahami, menyadari dan menilai dunia sosial (Dwizatmiko, 2010).

Bourdieu (2001) menyatakan dominasi laki-laki terhadap perempuan, dimana struktur-struktur sosial dan strukturstruktur aktivitas produktif dan reproduktif hadir atas dasar pembagian seksual yang memberikan bagian terbaik bagi laki-laki. Hal ini diafirmasikan dalam skema-skema yang terdapat dalam habitus. Bourdieu (2001) dalam Haryatmoko (2010) menyatakan habitus ada dalam diri semua orang secara universal. Oleh karena itu dominasi laki-laki terhadap perempuan hadir sebagai sesuatu yang pemahaman yang dianggap biasa. hal ini disebut dengan doxa. Khalayak menerima sebagai sesuatu yang wajar, sebagai wacana yang dominan atau doxa. Doxa adalah sudut pandang penguasa atau dominan yang menyatakan diri atau memberlakukan diri sebagai sudut pandang yang universal.

$$
\text { Doxa cenderung mendukung }
$$

pengaturan sosial tertentu pada ranah tersebut, dan dengan demikian mengistimewakan pihak yang dominan dan menganggap posisi dominan tersebut sebagai terbukti dengan sendirinya. Oleh karena itu, kategori-kategori pemahaman dan persepsi membentuk habitus (Bourdieu, 2001) menyatakan dominasi gender merupakan dasar kekerasan simbolik. Bourdiu menambahkan kekerasan simbolik merupakan model dominasi kultural dan sosial yang berlansung secara tidak sadar (unconscious) dalam kehidupan manyarakat meliputi diskriminasi, salah satunya diskriminasi terhadap gender. Terdapat relasi yang timpang antara yang mendominasi dan yang didominasi. Beate (1993) dalam Mustakim (2012). dominasi memiliki banyak rupa, diantaranya kekerasan fisik, pemaksaan, kekerasan structural yang dioperasikan oleh kekuasaan ekonomi, institusi sosial, intimidasi, dan kekerasan simbolik

(Haryatmoko, 2010) menyatakan wacana patriarki merupakan kekerasan karena menjebak perempuan dengan menentukan cara melihat, merasakan, berpikir, dan bertindak. Dalam dominasi laki-laki melalui wacana, terlihat cara bagaimana dominasi dilakukan dan diderita. Perempuan menjalaninya sebagai kepatuhan seakan wajar. Dominasi ini terlaksana melalui cara simbolis dalam komunikasi dan pengetahuan. Prinsip simbolik itu berupa bahasa, gaya hidup, cara berpikir atau bertindak, dan stigma.

Norma patriarki tersebut diinternalisasi menjadi habitus para pelaku sehingga tanpa disadari, para pelaku menjalankan peran masing-masing sebagai suatu kewajaran. Logika dominasi berjalan karena prinsip simbolis yang diterima dua pihak. Sudut panang kuat penilaian kuat ditentukan oleh budaya laki-laki. Bila di institusi sosial dan profesi didefenisikan atas dasar nilai dan kepentingan laki-laki, perkembangan selanjutnya merupakan proses diskualifikasi perempuan.

Wacana laki-laki mendikte perempuan. ketidak puasan harus dijelaskan dengan logika laki-laki. Lelaki menuntut 
alasan dan penjelasan. Dengan cara itu lakilaki menemukan kata-kata untuk membenarkan diri. Dengan debat dan adu argument adalah cara laki-laki memenangkan nilai-nilainya (Haryatmoko,2010). Perempuan merupakan korban intimidasi lewat pembenaran dominasi laki-laki. Pembagian kerja dalam hubungan antar suami dan istri adalah bentukan dan konstruksi sosial dan bukan kodrat karena bisa diubah. Pembagian kerja seharusnya menjadi pentukan dari consensus yang dihasilkan dari diskusi antar suami dan istri bukan menerima begitu saja apa yang seharusnya ada di masyarakat.

Lebih lanjut lagi, perempuan memandang dominasi simbolik yang dilakukan laki-laki sebagai sesuatu yang sah dan diterima. Perempuan ikut dalam ketundukannya (subordinasi) sendiri. Rasa kewajiban telah berhasil memaksanya secara lebih efektif, ketimbang dilakukan dengan teguran dan obrolan secara eksplisit. kedektatan dan ketundukan semacam ini tentu mempunyai implikasi serius terhadap proses internalisasi ideologis terhadap ketundukan perempuan terhadap laki-laki.

Kondisi dominasi ini digambarkan dalam media massa dengan membentuk sistem kekuasaan dalam media seperti mendominasi produksi, dan bahasa, dan makna yang beroperasi di dalam media tersebut (Hidayat, 2012). (Heitmeyer, Wilhelm dan Hagan, 2005) menyatakan kekerasan simbolik dapat ditemukan dalam media massa melalui kata-kata dan komunikasi yang mengandung kebencian dengan latar belakang rasis atau yang bersifat seksis. Bertujuan melukai integritas pribadi, etnis, atau seksual seseorang. Biasanya ditunjukkan dengan mengintimidasi dan merendahkan orang lain.

Sinetron merupakan salah satu media yang memproduksi kekerasan simbolik hampir setiap hari. (Udasmoro, 2013) dalam penelitiannya, mengungkapkan sinetron memproduksi narasi kekerasan simbolik setiap harinya melalui bahasa dan gambar. Dalam penelitiannya, setidaknya ada tiga aspek kekerasan simbolik yang sadar dan tidak sadar dibentuk oleh sinetron melalui bahasa dan gambar. Pertama, adalah konstruksi perempuan yang tersubordinasi termasuk didalamnya kelemahan dan kelembutan mereka. Kedua perempuan sebagai objek. Mereka diposisikan sebagai objek di depan laki-laki ataupun di depan perempuan lainnya yang berasal dari latar belakang ekonomi yang lebih tinggi. Aspek ketiga adalah yang disebut Baudrillard sebagai hiperrealitas .

\section{Feminisme dan Ideologi Patriarki}

Ideology dalam analisis Gramscian dipahami sebagai ide, makna dan praktik yang kendati mengklaim sebagai kebenaran universal, yang merupakan peta makna yang sebenarnya menopang kekuasaan kelompok tertentu. Ideology tidak dapat dipisahkan dari aktivitas praktis kehidupan, namun merupakan fenomena material yang berakar pada kondisi sehari-hari (Barker, 2000). Konsep ideology berdasarkan konsep Jorge Larrain (1996) dalam Sunarto (2000) memiliki pengertian yang bertolak belakang. Secara positif ideology dipersepsikan sebagai pandangan dunia yang menyatakan nilai-nilai kelompok sosial tertentu untuk memajukan dan membela kepentingan mereka. Sementara itu, secara negative ideology delihat sebagai suatu kesadaran palsu, yaitu kebutuhan untuk melakukan penipuan dengan cara memutarbalikan pemahaman orang mengenai realitas.

Di Indonesia ideologi patriarki adalah salah satu ideologi yang masih kental mewarnai berbagai aspek kehidupan dan struktur masyarakat. Pada tatanan kehidupan sosial, konsep patriarki sebagai landasan ideologis. Patriarki menjelaskan keadaan masyarakat menempatkan kedudukan dan posisi laki-laki lebih tinggi dari pada perempuan dalam segala aspek kehidupan sosial, budaya dan ekonomi (Rakoczy, 2004).

Patriarki menggambarkan sistem dominasi laki-laki baik di ruang publik dan lingkungan privat. Ideologi patriarki melebih-lebihkan perbedaan biologis antara pria dan wanita, memastikan bahwa laki-laki selalu memiliki peran yang dominan, atau maskulin, dan wanita selalu memiliki peran subordinat atau feminin. Mereka melakukannya melalui lembaga seperti akademi, gereja, dan keluarga, yang masingmasing membenarkan dan memperkuat 
subordinasi perempuan terhadap laki-laki". Struktur patriarkal telah menjadi 'cara hidup', sehingga perempuan telah dianggap tidak historis, dikukuhkan dan ditahbiskan oleh Tuhan (Rakoczy, 2004). Jadi patriarki adalah sistem struktur sosial dan praktik di mana laki-laki mendominasi, menindas dan mengeksploitasi perempuan.

Dalam budaya ini kedudukan perempuan ditentukan lebih rendah daripada laki-laki. dalam masyarakat ini terjadi dominasi laki-laki atas perempuan di berbagai bidang kehidupan. Sejarah patriarki muncul ketika agama di Eropa menentukan bahwa kawin somah (satu istri dan satu suami) merupakan perkawinan yang diakui gereja. Aturan ini meresmikan domestisitas perempuan (Murniati, 2004)

Pembatasan-pembatasan peran perempuan dalam budaya patriarki membuat perempuan terbelenggu. Budaya patriarki memberikan otoritas dan dominasi kepada laki-laki dalam kehidupan berumah tangga dan bermasyarakat. Selain itu pelekatan berbagai stereotype terhadap tubuh perempuan juga memperparah kondisi perempuan. Menurut Hall (1997) stereotype digunakan untuk mendefenisikan perempuan dan mengontrol mereka. Perempuan didefenisikan dengan hubungannya dengan laki-laki, bahwa perempuan diletakkan dengan ciri feminism. Perempuan diarahkan untuk bersikap dan berpenampilan seperti yang diharapkan laki-laki.

(Bhasin, 1996) menyatakan laki-laki mengontrol beberapa hal dalam system patriarki. Pertama laki-laki mengontrol daya produktif, atau ketenaga kerjaan perempuan. Kedua, laki-laki mengontrol reproduksi perempuan. Ketiga, laki-laki mengontrol seksualitas perempuan. Keempat, laki-laki mengontrol gerak perempuan dan laki-laki mengontrol harta dan sumber daya ekonomi lainnya.

Budianta (2002) menyatakan feminisme merupakan suatu kritik ideologi terhadap cara pandang yang mengabaikan masalah ketimpangan dan ketidakadilan dalam pemberian peran dan identitas sosial berdasarkan perbedaan jenis kelamin. Istilah feminisme berarti kesadaran akan adanya ketiakadilan jender yang menimpa perempuan, baik dalam keluarga atau pun masyarakat. (Gamble, 2001) mendefenisikan gerakan feminisme "A general definition might state that it is the belief that women, purely and simply because they are women, are treated inequitably within a society which is organised to prioritise male viewpoints and concerns"(p.vii). Dimana feminis merupakan upaya mengubah paradigma atau cara pandang berpikir masyarakat yang bersifat patriarki yaitu semua yang bersumber dari laki-laki.

Dalam paradigma patriarki, perempuan menjadi semua yang tidak ada pada laki-laki; dimana laki-laki dianggap sebagai yang kuat, perempuan lemah; di mana laki-laki rasional, perempuan emosional; dimana laki-laki yang aktif, perempuan pasif; dan seterusnya. Berdasarkan pemikiran ini, perempuan mengarah dengan negative. Sederhananya, feminisme berusaha untuk mengubah situasi ini. Feminisme berbicara tentang kesetaraan antar jenis kelamin dalam politik, sosial, dan ekonomi, juga mobilisasi yang teroganisir untuk menghapuskan diskriminasi terhadap perempuan yang berpusat pada pemberdayaan perempuan (Gamble, 2001).

Feminisme merupakan bagian dari budaya dan gerakan politik yang mengubah cara wanita berpikir dan mempengaruhi cara hidup wanita dan pria dalam mengartikan dunia ini (Hannam, 2007). Perbedaan pada laki-laki dan perempuan berorientasi pada budaya lebih menjelaskan berdasarkan pada peran mereka dalam kehidupan sosial yang lebih dikenal dengan konsep nurture. Konsep nurture membedakan laki-laki dan perempuan berdasarkan pada konstruksi sosial masyarakat. Adanya diferensiasi peran (division of labour) antara laki-laki dan perempuan bukan disebabkan oleh adanya perbedaan nature biologis, melainkan lebih disebabkan oleh faktor budaya

\section{Sinetron sebagai Cerminan Realitas}

Televisi merupakan media audiovisual sehingga tidak membebani banyak syarat bagi masyarakat untuk menikmatinya. Televisi mempunyai daya tarik yang kuat karena adanya audio yaitu, unsur-unsur kata, musik dan sound efect dan keunggulang unsur visual yaitu berupa gambar yang hidup dapat menimbulkan kesan yang mendalam bagi pemirsanya. Salah satu tayangan televisi yang diminati 
oleh masyarakat Indonesia adalah sinetron. Setiap harinya, berdasarkan pantauan lembaga survey ACNielson selama tahun 2013 dan tahun 2014 sinentron tidak pernah keluar dari 20 deretan teratas yang mendapatkan rating tertinggi. Dimana TVR mencapai 6,5 dengan share diatas 25 (sumber; Ariana Nilesen).

Sinetron merupakan singkatan dari sinema elektronik, dimana elektronik maksudnya disisni mengacu pada medium penyiarannya yaitu melalui televisi atau televisual. Televisi merupakan medium elektronik selain radio. Sinetron secara teknis hapir mirip dengan film layar lebar. Penggarapan sinetron dan film layar lebar memiliki kesamaan dalam pengambilan gambar, penokohan, penulisan naskah, isi scenario, format naskah dan lainnya. Perbedaan dari keduanya adalah, jika film layar lebar menggunakan kamera optik, pita selluloid, dan proyektor untuk menayangkannya, sedangkan sinetron menggunakan kamera elektronik dengan video recorder dan televisi sebagai media penayangannya.

Sinetron dalam bahasa Inggris disebut soap opera (opera sabun), sedangkan dalam bahasa Spanyol disebut telenovela. Di Indonesia, banyak genre opera sabun atau sinetron, ada sinetron drama yang menceritakan tentang konflik dalam kehidupan, sinetron horor yang menceritakan tentang kisah-kisah yang bersifat alam gaib atau mistis, sinetron komedi yang bercerita tentang kisah yang humor dan konyol, sinetron religi yang menceritakan kisah-kisah religi dan sinetron percintaan yang menceritakan kisah tentang percintaan atau pacaran yang biasanya bertema romantisme.

Unsur-unsur sinetron adalah (1) "serialitas," penggunaan cliffhangers dan penggoda untuk menjaga audiens terpaku pada narasi; (2) "orientasi waktu nyata," kunci dari peristiwa diegetik dengan ritme kehidupan sehari-hari, liburan sipil, kelahiran, kematian, dan lain-lain, serta "gerak kamera. . . dirancang untuk menyerupai persepsi peristiwa aktual " (3) "orientasi keintiman / permainan yang tampak," menumbuhkan rasa tahu "kegelisahan" di antara penonton dan dorongan simultan untuk bergosip tentang karakter dan peristiwa (misalnya, bertukar sekitar program realitas); (4) "eksposisi cerita," konstruksi narasi opera sabun yang sangat redundan yang memberi penonton perasaan maha tahu dan juga memungkinkan mereka untuk menghargai narasi secara ironis (misalnya, mereka dapat mengakui dan menikmati absurditas banyak plot opera sabun) ); dan (5) "tema opera sabun," fokus pada konflik antarpribadi (hubungan cinta / benci), pengulangan ritualistik konflik, dan proyeksi "kehidupan yang baik (Wittebols, 2004).

Genre sinetron tersebut tidak terlepas dari konteks budaya.Contohnya, budaya Indonesia yang mempercayai kisah-kisah yang bersifat alam gaib atau mistis melahirkan sinetron genre horror. Film dan sinetron merupakan media massa yang digunakan untuk menampilkan ulang realitas yang terjadi di lingkungan sosial sekitar kita. Secara tidak sadarfilm merupakan salah satu representasi dari realitas yang ada di masyarakat.

Konstruksi realitas berasal dari media massa dan konstruksi realitas di media massa berasal dari realitas sehari-hari. (Siregar, 2004) dalam penelitiannya mempertegas media berperan besar dalam mengkonstruksi realitas. Media menjadi reflector bagi kehidupan nyata maupun kehidupan fiksional manusia. Sinetron merupakan produk media yang mampu menggiring alam pikiran manusia hingga pada akhirnya bisa merubah pola hidup, baik yang positif dan negatif di tengah-tengah kehidupan manusia. Bagi pembuat dan khalayaknya, sinetron juga merupakan praktek sosial yang tidak lepas dari unsurunsur ideologi dan propaganda yang terkandung di dalamnya.

(Hassan, 2018) menyataka televisi adalah media yang menembus, mampu menciptakan kesadaran palsu di antara pemirsa.Dalam konteks media, ideologi sebagai system makna yang membantu menjelaskan dan mendefinisikan realitas dan membantu dalam membuat nilai-nilai pembenaran atas realitas itu. Ideologi bukan hanya untuk meyakini realitas, namun juga cara dasar untuk mendefinisikan realitas. Media adalah ruang dimana berbagai ideology direpresentasikan. Hal ini berarti disatu sisi media bisa menjadi sarana penyebaran ideology penguasa, alat 
legitimasi, dan control atas wacana public. Namun, disisi lain media juga bisa menjadi alat resistansi terhadap kekuasaan, media bisa menjadi alat untuk membangun kultur dan ideology dominan bagi kepentingan kelas dominan, sekaligus juga bias menjadi instrument perjuangan bagi kaum tertindas untuk membangun kultur dan ideology tandingan (Eriyanto, 2001).

Sinetron Indonesia sangat bergantung pada tema dan setting sosial yang dibangun atas "permintaan pasar". Perempuan adalah objek utama yang tetap menarik untuk ditampilkan di sinetron. Tema-tema sinetron pada umumnya fokus pada kehidupan perempuan. Perempuan selalu menjadi topik utama yang mengalami masalah kehidupan yang berat. Perempuan sebagai pemeran tokoh utama. Digambarkan karakternya lemah, cengeng, mengalah, dan tertindas, sudah bukan lagi menjadi hal baru. Perempuan selalu dominan namun juga selalu dieksploitasi.

Salah satu sinetron memiliki tema kental tentang perempuan adalah sinetron yang berjudul Catatan Hati Seorang Istri. Tokoh utama yang ditonjolkan dari sinetron ini adalah perempuan, yaitu Hana dengan dua sahabatnya Vina dan Anisa. Fokus ceritanya adalah bagaimana Hana dan dua temannya tersebut sebagai perempuan, ibu, dan istri menyelesaikan permasalahan mereka. Hana, sebagai seorang penulis blog konsultan masalah perempuan dituntut bersikap tegar, mandiri dan bijaksana, meskipun dia berada pada tekanan masalah rumah tangga. Salah satu ciri khas sinetron adalah perempuan dan sentral.Penelitian ini mengangkat sinetron ini sebagai objek penelitian karena tema sinetron ini memiliki tema tentang perempuan. Dengan asumsi sinetron ini berusaha menampilkan sosok perempuan modern, namun tetap kental dengan budaya patriarkinya, dan diduga terdapat kekerasan simbolik dalam sinetron tersebut.

\section{METODE PENELITIAN}

Penelitian dengan pendekatan kritis ini bertujuan untuk mengungkapkan kekerasan simbolik terhadap perempuan yang ditampilkan dalam sinetron melalui penokohan perempuan. Dengan menggunakan tipe kualitatif, penelitian ini diharapkan dapat memberikan rincian yang lebih kompleks tentang fenomena kekerasan simbolik terhadap perempuan dalam sinetron.

Salah satu konsep analisis wacana yang bertujuan membongkar ideologi, adalah analisis wacana yang dikenalkan oleh Sara Mills. Titik perhatian dari konsep ini adalah pada wacana mengenai feminisme, yaitu wacana bagaimana wanita ditampilkan dalam teks, baik gambar, foto, novel ataupun berita. Sara Mills dikenal sebagai ahli wacana yang banyak menulis mengenai representasi perempuan. Penggambaran yang buruk dan ketidakadilan mengenai perempuan merupakan sasaran dari tulisan Sara Mills. Perempuan cendrung ditampilkan sebagai pihak yang salah dan marginal disbanding dengan laki-laki (Eriyanto, 2001).

Analisis wacana ini menunjukkan bagaimana perempuan digambarkan dan dimarjinalkan dalam teks, dan bagaimana bentuk pemarjinalan tersebut dilakukan.Hal ini tentu saja menggunakan strategi wacana tertentu sehingga ketika ditampilkan dalam teks, perempuan tergambar secara buruk. Dalam menganalisis teks dalam skala wacana, melihat posisi actor, Mills menyatakan tidak harus terikat dengan gaya bahasa, melainkan lebih memperhatikan konteks yang lebih luas dan struktur narasi teks. Melalui struktur dan narasi teks, Mills menganalisis berdasarkan kerangka cerita berdasarkan empat aspek yaitu; karakter, fragmentation, focalizations, dan schemata. Keempat aspek tersebut memberikan pemahaman yang lebih jelas mengenai bias gender (Eriyanto, 2001)

Mills (1995) menyatakan karakter merupakan suatu yang dibentuk. Karakter terbuat dari kata-kata, dimana pembaca telah belajar bagaimana mengkonstruksi ke dalam satu set penggambaran pesan ideologis dan pandangan yang beredar di dalam masyarakat. Menyampaikan karakter suatu tokoh menentukan pesan ideology dominan yang akan disampaikan melalui cerita tersebut. Kerangka kedua yang digunakan Sara Mills (1995) dalam mengungkap ideology suatu teks adalah melalui fragmentation. Fragmantation bagaimana penulis atau sutradara mengacu pada mengotak-kotakan tubuh dalam hal 
pengambaran tokoh, terutama perempuan. Bagian tubuh perempuan yang ditampilkan berdasarkan sudut pandang laki-laki yang terdiri dari bagian -bagian tubuh tertentu, yaitu bagian yang menurut laki-laki menarik dari segi seksualitas. Aspek yang ketiga adalah focalization atau focus teks. Hal ini mengacu pada sudut pandang siapa teks digambarkan. Pada kerangka cerita ini, melihat focus cerita dengan menentukan porsi suara yang dominan yang digambarkan dalam teks. Selanjutnya aspek yang terakir, adalah schemata yaitu kerangka yang paling luas, karena berhubungan dengan cara pikir, cara pandang, dan kepercayaan secara umum. Schemata merupakan gambaran secara cultural. Dari keseluruhan analisis, bagaimana posisi perempuan digambarkan dalam sinetron sesuai dengan budaya yang dianut oleh Indonesia (Eriyanto, 2001).

Penelitian ini menggunakan metode analisis wacana dipaparkan oleh Sara Mills dengan melihat posisi-posisi perempuan dalam sinetron. Objek penelitiannya adalah sinetron Catatan Hati Seorang Istri. Pemilihan sinetron ini sebagai objek penelitian karena sinetron ini merupakan sinetron yang diminati oleh penonton, dapat dilihat melalui ratingnya yang tinggi mencapai 7,0 dengan share 32,2. Sinetron ini mengangkat permasalahan perempuan dan diangkat dari sudut pandang perempuan melalui tokoh-tokoh perempuan.

Penelitian ini menggunakan analisis wacana Sara Mills, dimana analisis wacana ini menunjukkan bagaimana perempuan digambarkan dan dimarjinalkan dalam teks, dan bagaimana bentuk pemarjinalan tersebut dilakukan. Oleh karena itu, unit analisis dari penelitian ini adalah tokoh-tokoh utama perempuan. Analisis dilakukan dengan mengumpulkan data primer berupa teks sebagai data primer. Data primer berupa rekaman sinetron Catatan Hati Seorang Istri yang akan diteliti terdiri 15 episode. Selanjutnya juga dibutuhkan studi pustaka dan kajian literature sebagai data sekunder.

Perempuan adalah objek utama yang tetap menarik untuk ditampilkan di sinetron. Tema-tema sinetron pada umumnya fokus pada kehidupan perempuan. Perempuan selalu menjadi topik utama yang mengalami masalah kehidupan yang berat. Seringkali perempuan berperan sebagai tokoh utama. Tokoh perempuan sebagai central cerita biasanya perempuan protagonis yang digambarkan karakternya sebagai perempuan baik namun sering tertindas, mengalah lemah, dan cengeng, selain itu karakter antagonis perempuan digambarkan sebagi karakter yang jahat perusak rumah tangga orang, matrealistis dan lainnya. Namun demikian, perempuan tersebut digambarkan tetap tunduk pada laki-laki. Misalnya, konsep istri yang baik adalah istri yang menuruti perintah suami, yang mau menutupi aib suami, yang mau mengalah untuk kepentingan suami dan lainnya, begitu juga konsep wanita jahat, biasanya diakibatkan oleh tokokh laki- laki. Perempuan selalu dominan namun juga selalu dieksploitasi.

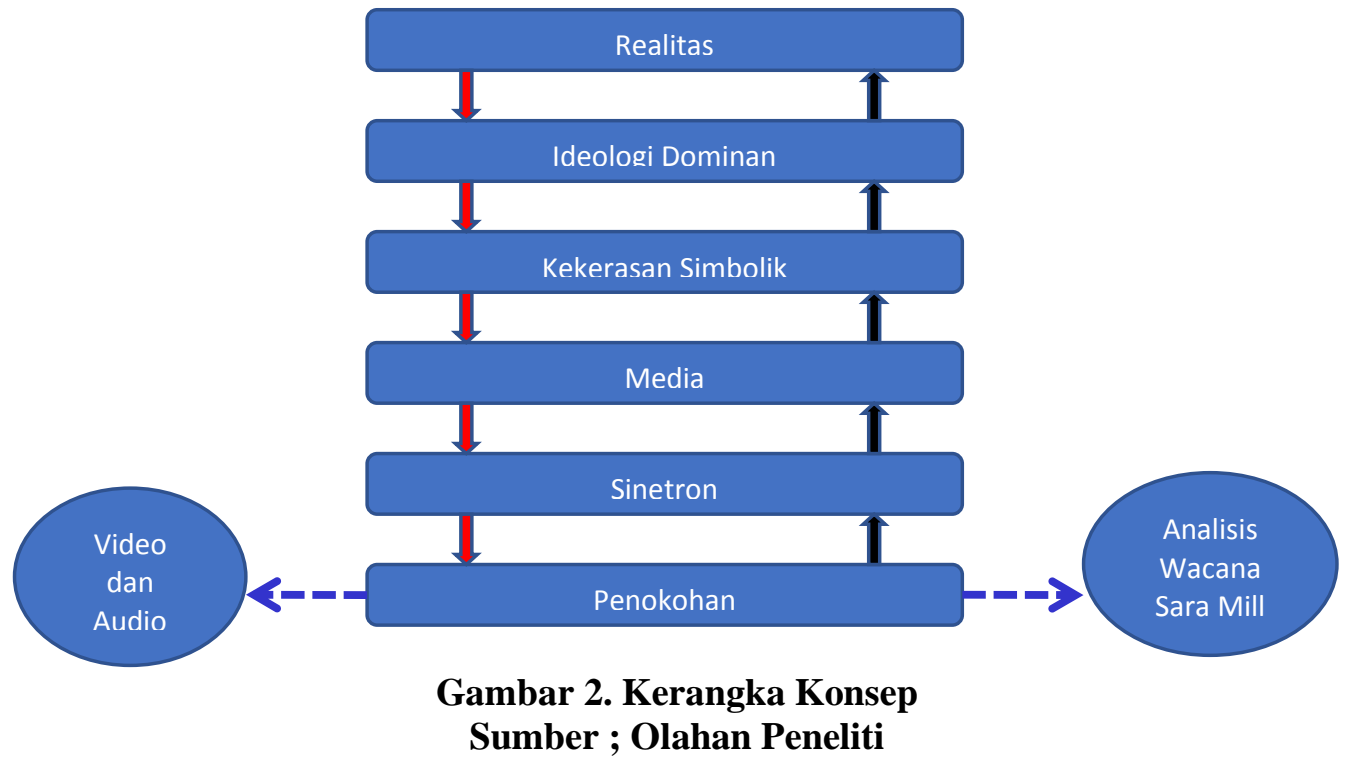


Penokohan perempuan sebagai objek tidak terlepas dari ideology patriarki yang dianut oleh masyarakat kita. Patriarki menggambarkan sistem yang dilembagakan dominasi laki-laki. Meskipun perempuan sebagai tokoh utama, tetapi tetap sebagai objek. Konsep tersebut terkait pada asumsi feminis, bahwa perempuan didefinisikan dari sudut pandang laki-laki, sehingga laki-laki adalah subjek dan perempuan adalah objeknya. Adanya dominasi membuka jalan untuk terjadinya kekerasan simbolik. Hal inilah yang menjadi focus penelitian, dimana sinetron tentang perempuan namun berlandaskan ideology patriarki yang mengundang kekerasan simbolik terhadap tokoh perempuan tidak disadari oleh penontonnya yang sebagian besar perempuan.

Dalam membongkar kekerasan simbolik terhadap perempuan penelitian ini menggunakan analisis wacana Sara Mills. Analisis ini membongkar ideology suatu teks melalui penokohan. Menggunakan data video dan audio, Sara Mills menganalisis berdasarkan kerangka cerita berdasarkan empat aspek yaitu; karakter, fragmentation, focalizations, dan schemata. Hal ini dapat dijelaskan dalam kerangka pemikiran dalam gambar 2 .

\section{HASIL DAN PEMBAHASAN}

Penelitian ini bertujuan mengungkapkan kekerasan simbolik dengan membongkar ideologi dominan yang ditampilkan oleh sinetron Catatan Hati Seorang Istri. Dalam bab ini, peneliti membongkar ideologi dominan dengan menganalisis penggambaran tokoh perempuan dalam sinetron tersebut. Peneliti menganalisis adegan pilihan yang memaparkan penggambaran karakter tokoh perempuan dalam sinetron. Peneliti menggunakan analisis wacana Sara Mills untuk membedah kekerasan simbolik beroperasi pada sinetron melalui penokohan.

$$
\text { Sara Mills mengungkapkan }
$$

bagaimana ideologi yang mendominasi dalam sinetron dengan melihat posisi tokoh dalam penokohan melalui kerangka cerita karakter, fragmentation, focalitation dan schemata. Mills menyatakan karakter merupakan suatu yang dibentuk.
Fragmentasi, yaitu bagaimana penulis atau sutradara mengacu pada mengotak-kotakan tubuh dalam hal pengambaran tokoh, terutama perempuan. Focalization atau focus teks mengacu pada sudut pandang siapa teks digambarkan. Aspek yang terakhir, schemata, adalah kerangka yang paling luas, karena berhubungan dengan cara pikir, cara pandang, dan kepercayaan secara umum. Schemata merupakan gambaran secara cultural atau budaya. Dari Peneliti menganalisis dengan membagi tokoh perempuan menjadi empat bagian sesuai dengan karakter perempuan dalam sinetron Catatan Hati Seorang Istri. Pertama, tokoh perempuan yang merupakan korban selingkuhan. Kedua, adalah perempuan yang menjadi pelaku selingkuh. Ketiga, perempuan yang menjadi korban kekerasan dalam rumah tangga. Terakhir, perempuan yang merupakan orang tua tunggal. Setiap karakter membawa permasalahan dan cara penyelesaian masalah dengan pola pikir yang berbeda-beda juga. Sehingga, sinetron ini menggambarkan tokohnya melalui habitushabitus dilakukan dan doxa yang dipercaya oleh masing-masing tokoh. Habitus dan dan doxa yang diperankan oleh masing-masing tokoh mempengaruhi bentuk dominasidominasi yang dilakukan laki-laki terhadap perempuan dalam sinetron ini.

keseluruhan analisis, bagaimana posisi perempuan digambarkan dalam sinetron sesuai dengan budaya yang dianut oleh Indonesia (Eriyanto, 2001).

Pada kategori perempuan yang menjadi korban selingkuhan, Sinetron ini menempatkan perempuan sebagai subjek dengan menggambarkan perempuan menjadi panutan karena sukses dan memiliki keluarga yang harmonis. Sebagai objek, sinetron ini menggambarkan perempuan sebagai korban perselingkuhan. Sinetron ini menggambarkan perempuan sebagai korban perselingkungkuhan dengan menempatkan perempuan sebagai pihak yang lemah, mengalah, tertindas dan cendrung tidak bersuara menyampaikan pendapatnya. Hal tersebut merupakan bentuk kekerasan simbolik yang tidak terlepas dari adanya dominasi laki-laki dibaliknya.

Tokoh perempuan yang menjadi korban perselingkuhan, yaitu Hana. Hana merupakan tokoh utama dalam sinetron 
Catatan Hati Seorang Istri. Sinetron ini mengangkat cerita dari sudut padang tokoh Hana. Cerita berpusat pada bagaimana karakter Hana menjalani perannya sebagai seorang istri sehari-hari, bagaimana tokoh Hana menghadapi dan menyikapi permasalahan rumah tangganya, dan bagaimana tokoh ini mengambil keputusan terhadap permasalahan rumah tangganya. Karena itu, tokoh, Hana mendapatkan porsi suara yang lebih banyak dalam menampilkan konflik permasalahan rumah tangganya dalam sinetron ini. Mengacu pada aspek focalization atau fokus cerita, sinentron ini memiliki fokus cerita dari sudut pandang perempuan yang dikhianati oleh suaminya.

Hana sebagai sentral cerita juga menunjukkan posisinya sebagai protagonist dalam sinetron ini. Tokoh protagonis adalah tokoh yang wataknya disukai penonton, biasanya watak tokoh semacam ini adalah watak yang baik dan positif. Pada protagonis, penonton menaruh harapan besar, yang tidak sesuai dengan harapan akan membuat penonton kecewa. Penonton akan bersimpati, berempati bahkan larut dalam keadaan tokoh protagonist. Karena itu, tokoh utama protagonis identik membawa sifatsifat baik yang menarik perhatian penonton. Deskripsi yang baik tentang keadaan fisik tokoh dan atau keadaan batin tokoh menentukan seberapa minat menonton.

(Belenky, M.F, 1989) menyatakan perempuan belajar mengadopsi dari sudut pandang laki-laki. Sinetron ini menggambarkan perempuan cantik untuk laki-laki, menjadikan standar cantik juga ditentukan oleh selera laki-laki. Hal ini menunjukkan bahwa perempuan secara tidak sadar didominasi laki-laki, yang mengakibatkan kekerasan secara halus.

Pada tokoh perempuan sebagai pelaku selingkuh biasa diidentikan sebagai pelaku kejahatan rumah tannga. Perempuan dengan sebagai pelaku selingkuh biasa dilabeli sebagai perusak rumah tangga orang. Sinetron ini menggambarkan perempuan kategori ini dengan berbagai sifat negative sehingga dibenci penonton. Sinetron ini menampilkan perempuan kategori ini sebagai perempuan yang termarginal karena perannya sebagai perempuan selingkuhan. Posisi tersebutlah yang melatarbelakangi karakter ini memperjuangkan haknya sebagai perempuan, namun demikian sikap tokoh tersebut memperburuk label negative tokoh ini. Hal tersebut merupakan bentuk diskriminasi terhadap perempuan yang secara tidak sadar menimbulkan kekerasan simbolik terhadap perempuan.

(Berger, 2005) membagi karakter suatu cerita menjadi 31 bagian, salah satunya adalah penjahat. Kategori kedua adalah tokoh perempuan sebagai pelaku selingkuh, yang biasa diidentikan sebagai pelaku kejahatan rumah tannga. Perempuan dengan sebagai pelaku selingkuh biasa dilabeli sebagai perusak rumah tangga orang. Sinetron ini menggambarkan perempuan kategori ini dengan berbagai sifat negative sehingga dibenci penonton.

Tokoh antagonis adalah tokoh yang wataknya dibenci pembacanya. Tokoh ini biasanya digambarkan sebagai tokoh yang berwatak buruk dan negative, Namun, ada juga tokoh-tokoh antagonis yang bercampur dengan sifat-sifat yang baik. Sinetron ini menggambarkan bahwa perempuan yang berselingkuh dengan suami perempuan lain adalah perempuan tidak baik dan pengganggu. Bahkan, sinetron ini mencoba menggambarkan bahwa tokoh Karin yang berselingkuh dengan suami lain memang sudah memiliki karakter pengganggu sejak kecil.

Sinetron ini member label pada tokoh Karin, hal tersebut merupakan diskriminasi terhadap perempuan yang mengakibatkan kekerasan simbolik. Label pengganggu memberikan streotipe merendahkan perempuan. Pelabelan terhadap salah satu jenis kelamin yang sering kali bersifat merendahkan dan pada umumnya menyebabkan terjadinya ketidakadilan. Perempuan dengan label pengganggu memberikan stereotype bahwa perempuan pengganggu adalah orang yang dituduh menghancurkan rumah tangga orang. Sementara itu, stereotype ini tidak berlaku pada laki-laki. Laki-laki tidak pernah diberi label "laki-laki pengganggu".

Pada katergori perempuan sebagai korban KDRT, yang menjadi fokus peneliti bukan kekerasan fisik yang diterima tokoh, melainkan bagaimana tokoh dalam sinetron ini menerima situasi kekerasan yang diterimanya tanpa melawan, bagaimana perempuan tersebut melindungi pelaku 
kekerasan, dan bagaimana perempuan tersebut tidak bersuara memperjuangkan haknya. Hal ini tidak terlepas dari peran si penguasa yaitu suami dari tokoh ini. Dominasi yang dilakukan oleh si penguasa mengakibatkan perempuan bergantung lakilaki. Kekuasaan laki-laki terhadap perempuan pada peran ini mengakibatkan kepatuhan dan ketakutan yang merepresentasikan perempuan sebagai makhluk yang lemah, tertindas, teraniaya dan juga submisif. Hal tersebut merupakan wujud dari kekerasan simbolik terhadap perempuan.

Tokoh Karin yang mau menjadi perempuan kedua dilakukan Karin dengan pengorbanan. Perempuan berkorban merupakan wujud dari budaya patriarki. Namun demikian, penggambaran rela berkorban pada tokoh Karin digambarkan secara negatif. Tokoh Karin digambarkan sebagai perempuan yang rela diposiskan sebagai perempuan kedua setelah istrinya. Tokoh Karin menerima hubungannya dilakukan tanpa ikatan pernikahan, tanpa status yang legal.Sementara laki-laki dalam hal ini melepaskan tanggung jawabnya.

Pada kategori peran perempuan sebagai orang tua tunggal, sinetron ini menggambarkan perempuan bersifat protektif dan emosional dalam menghadapi perannya. Sikap protektif perempuan pada kategori ini dilatarbelakangi oleh masa lalunya yang pernah tersubordinat oleh lakilaki. Tokoh perempuan ini menjadi lebih protektif dan emosional ketika berhadapan dengan laki-laki terutama laki-laki di masa lalunya. Perempuan bersikap protektif merupakan bentuk perlawanan perempuan terhadap dominasi laki-laki kepada mereka. Namun demikian sikap emosional juga kembali mempertegas mitos perempuan bersikap berdasarkan perasaannya bukan rasionalnya.

Tokoh berikutnya adalah Annisa yang merupakan tokoh utama tambahan. Permasalahan yang terjadi pada tokoh Annisa merupakan salah satu cerita utama dalam sinetron ini. Tokoh Annisa mewakilkan cerita tentang perempuan yang menjadi korban kekerasan dalam rumah tangga. Suami Annisa kerap main tangan terhadap Annisa jika istrinya tersebut melakukan kesalahan.
Anisa merahasiakan perlakuan suaminya salah satunya karena laki-laki tersebut merupakan suami Anisa. Anisa merupakan perempuan yang sangat menganut budaya patriarki. Laki-laki memiliki kekuasaan terhadap rumah tangga yang dipimpinnya, dan Anisa mematuhi hal tersebut. Pemikiran Anisa tersebut telah mendarah daging atau sudah ada dalam alam bawah sadarnya mengendalikan tindakantindakan yang akan dilakukan Anisa. Kewajiban bagi perempuan menjaga nama baik suami. Pemikiran tersebut menjadi doxa bagi Anisa yang mempengaruhi habitusnya.

Haryatmoko (2010) menyatakan doxa merupakan sudut pandang penguasa atau dominan yang menyatakan diri atau memberlakukan diri sebagai sudut pandang yang universal. Secara universal dalam budaya patriarki, istri yang baik adalah istri yang menutupi aib suaminya. Pernyataan tersebut juga didukung oleh agama.

\section{Analisis}

Perempuan menjadi tokoh sentral dalam sinetron di Indonesia. Namun, perempuan sebagai tokoh utama justru tidak menempatkan perempuan sebagai kelompok yang memiliki suara. Sebaliknya, sintron justru memperlakukan perempuan sebagai objek kekerasan simbolik yang utama. Perempuan mendapat 'tempat' dalam sinetron, namun juga 'ditempatkan'. Karena itu, penokohan perempuan dalam sinetron pun harus sesuai dengan budaya patriarki sehingga melanggengkang dominasi lakilaki.

Berdasarkan analisis tokoh perempuan berdasarkan perannya, peneliti mengeneralisasikan dominasi yang dilakukan laki-laki terhadap perempuan menjadi dua bagian. Pertama, perempuan menerima dominasi dari laki-laki tanpa perlawanan, karena perempuan tersebut masih terikan dengan lembaga keluarga yang mengikat perempuan berada dibawah kuasa laki-laki. Hal ini terjadai pada perempuan dengan peran perempuan sebagai korban perselingkuhan dan perempuan sebagai korban KDRT. Pada kategori ini perempuan menerima dominasi dan terikat dengan lembaga yang melanggengkan dominiasi tersebut sehingga perempuan memilih tidak bersuara. 
Ketika seorang perempuan menjadi selingkuhan maka dia secara tidak sadar menyetujui dan menerima kondisi dan syarat yang ditetapkan oleh laki-laki. Persyaratan tersebut, yaitu tidak mengumumkan mengenai perselingkuhan mereka. Perempuan 'dipaksa' menyetujui hal ini demi kepentingan laki-laki. Padahal, persyaratan itu demi kepentingan laki-laki. Tokoh Karin harus menyembunyikan hubungannya dengan Bram demi kepentingan Bram yang tidak ingin hubungannya dengan Karin diketahui istri dan keluarganya. Oleh karena itu, Karin menjadi perempuan yang rela berkorban.

Karin dapat sebenarnya mengetahui hubungan yang dia jalani merupakan hubungan yang salah. Namun demikian pengetahuannya tersebut diabaikan oleh Karin. Belenky et.al (1989) menyatakan perempuan bungkam meskipun dia melihat sesuatu yang salah. Karin menerima status sebagai selingkuhan meskipun dia tahu bahwa status tersebut akan ditentang oleh masyarakat. Karin mengikuti Bram karena Karin patuh pada Bram. (Belenky, M.F, 1989) juga menyatakan perempuan melakukan sesuatu terkadang dilatarbelakangi oleh alasan yang tidak jelas. Belenky memberikan contoh, perempuan yang hamil diluar nikah tidak menggugurkan kandungannya karena di minta oleh ibunya. Perempuan tersebut melakukan hal itu karean ia mematuhi ibunya, bukan karena alasan lainnya. Begitu juga dengan Karin yang mematuhi aturan Bram karena yang meminta adalah Bram, bukan karena alasan lainnya.

Kedua, perempuan menerima dominasi sadar mereka berada dibawah kuasa laki-laki memilih mengambil sikap dengan berusah melawan dan bersuara memperjuangkan haknya, dan melakukan perlawanan terhadap dominasi yang mereka terima. Hal ini dilakukan oleh perempuan yang memerankan pelaku perselingkuhan dan perempuan sebagai orang tua tunggal. Dimana pada peran yang mereka jalani, mereka tidak terikat dengan lembaga atau status legal lainnya.

Perempuan dalam sinetron mendapatkan peran sebagai tokoh utama dengan penggambaran sebagai berikut: mengalah, penyabar, berkorban demi kepentingan laki-laki, dan menahan penderitaan. Perempuan dalam sinetron juga 'rela' dipertarungkan dengan perempuan lain demi mendapatkan perhatian, kasih sayang, dan cinta dari laki-laki. Sinetron juga merepresentasikan perempuan sebagai istri yang tunduk pada suami, penurut, emosional, merasa bersalah ketika suami melakukan kesalahan. dan dapat menjadi jahat ketika memperjuangkan hak-haknya.

Penokohan seperti menunjukkan bahwa perempuan adalah korban kekerasan (Rohimi, 2012). Bourdieu (1991) menjelaskan kekerasan dalam bentuk tersebut sebagai kekerasan simbolik. Kekerasan simbolik merupakan kekerasan yang tidak tampak, terjadi ketika adanya keterlibatan orang-orang yang tidak ingin tahu bahwa mereka merupakan sasaran dan mereka menjalankannya setiap hari. Bourdieu (1991) menyatkan dominasi gender merupakan akar kekerasan simbolik. Bentuk dominasi laki-laki terhadap perempuan ditunjukkan pada representasi perempuan yang rela membungkuk, merendahkan diri, meringkuk dan menempatkan diri di bawah (Bourdieu, 2001).

Pada sinetron ini bentuk dominasi yang menjadi dasar kekerasan simbolik dijabarkan menjadi empat bagian. Pertama, dominasi mengatas namakan kewajiban. Pada bagian ini perempuan ditempatkan berkewajiban wilayah domestik. Perempuan dianggap sukses adalah perempuan yang memiliki peran ganda yaitu berkewajiban diwilayah domesik dan di ruang public. Kedua, dominasi menempatkan perempuan sebagai objek seksual. Pada bagian ini perempuan dijadikan alat pemuas kebutuhan laki-laki. Perempuan ditempatkan dibawah laki-laki sebagai pemenuhan kepuasana seksual laki-laki. Ketiga, dominasi dengan menutup mulut perempuan. Perempuan berada dibawah kekuasaan laki-laki cendrung takut untuk mengambil keputusan. Perempuan cendrung mengikuti apa yang diinginkan oleh pihak yang berkuasa yaitu laki-laki. Sehingga perempuan tidak mengeluarkan suara mengaspirasikan pendapat mereka. Namun demikian, dominasi menyebabkan perempuan bersuara. Perempuandigambarkan bisa melawan lakilaki dalam memperjuangkan haknya. Hanya saja, sinetron ini menggambarkan perempuan tersebut sebagai perempuan agresif, 
emosional bahkan menempatkan perempuan sebagai perempuan yang jahat.

Sinetron pun menjadi agen untuk memproduksi kekerasan simbolik melalui penokohan para perempuan sehingga secara tidak sadar masyarakat mengintimidasi dan merendahkan perempuan. Kekerasan simbolik terhadap perempuan yang berlangsung setiap hari di layar kaca ini mengukuhkan ketimpangan relasi kuasa antara perempuan dan laki-laki di masyarakat.

Sinetron mengemas narasi yang tidak disadari para penonton untuk menanamkan ideologi dengan tujuan melanggengkan dominasi laki-laki atas perempuan. Bourdieu (2001) menyebut hal ini sebagai doxa. Khalayak menerima sebagai sesuatu yang wajar, sebagai wacana yang dominan atau doxa. Doxa adalah sudut pandang penguasa atau dominan yang menyatakan diri atau memberlakukan diri sebagai sudut pandang yang universal (Haryatmoko, 2010).

\section{KESIMPULAN}

Berdasarkan hasil analisis yang telah dijabarkan pada bab empat, peneliti mendapatkan beberapa kesimpulan. Sinetron ini menceritakan kisah perempuan dari sudut pandang perempuan. Namun demikian, sinetron Catatan Hati Seorang Istri melanggengkan ideologi patriarki sebagai ideologi dominan. Sinetron ini mengadopsi norma-norma patriarki dalam setiap aspek penyajiannya, terutama penokohan perempuan yang menjadi fokus dalam penelitian ini. Cara produser sinetron menggambarkan atau melukiskan tokoh dalam Catatan Hati Seorang Istri tidak lepas dari peran perempuan yang berada di bawah atau subordinasi laki-laki. Hal tersebut mejawab pertanyaan penelitian pertama tentang ideology dominana yang terdapat dalam sinetron ini.

Perempuan menjadi tokoh sentral dalam sinetron. Namun, perempuan sebagai tokoh utama justru tidak menempatkan perempuan sebagai kelompok yang memiliki suara. Adanya dominasi membuka jalan untuk terjadinya kekerasan simbolik. Bentuk dominasi yang menjadi dasar kekerasan simbolik pada sinetron ini dijabarkan menjadi empat bagian. Pertama, dominasi mengatas namakan kewajiban; kewajiban wilayah domestik. Kedua, dominasi menempatkan perempuan sebagai objek seksual. Ketiga, dominasi dengan menutup mulut perempuan. Namun demikian, dominasi menyebabkan perempuan bersuara.

\section{Saran}

Ideologi patriarki merupakan salah satu yang mendasari kekerasan simbolik. Melalui penelitian ini diharapkan, bisa membuka pemikiran bahwa kekerasan simbolik bisa beroperasi melalui penokohan. Secara praktis melalui penelitian ini diharapkan, bagi lembaga-lembaga pengawas media sadar dengan bentuk kekrasan simbolik yang setiap hari tampil di televisi. Bagi pelaku industry televisi lebih teliti dalam menggambarkan perempuan. Pelaku media diharapkan memahami konsep-konsep kekerasan simbolik sehingga pelaku industry media dapat menghadirkan tayangan yang lebih ramah terhadap perempuan, tayangan yang tidak menampilkan kekerasan simbolik.

Secara sosial diharapkan kepada masyarakat agar lebih kritis menyikapi konten sinetron. Media massa adalah agen reproduksi ideology salah satunya ideologi patriarki. Sinetron merupan tayangan yang dibayang-bayangi ideology patriarki yang rentang memproduksi kekerasan simbolik. Bagi para penikmat sinetron diharapkan mendapat gambaran tayangan yang mengandung kekerasan simbolik, karena kekerasan simbolik merupakan kekerasan yang tidak disadari. Selanjutnya perempuan diharapkan lebih cermat memilh dan meneliti tayangan sinetron terutama tentang perempuan.

\section{DAFTAR PUSTAKA}

Alnashava, P. (2012). Dalam Serial Komedi Situasi How I Met Your Mother. Universitas Indonesia.

Barker, C. (2000). Cultural STudies. London: Sage.

Belenky, M.F, C. B. M. . G. N. R. . \& T. J. M. (1989). Knowing; The Development of Self, Voice and Mind. New York: Basic group Inc. 
Berger, A. A. (2005). Media Ananlysiis Techniques (Third Edition). California: SAGE Publications.

Bhasin, K. (1996). What Is Patriarchy (N. Katjasungkana, Ed.). New Delhi: Women Unlimited.

Bourdieu, P. (2001). Masculine Domination, (R. Nice, Ed.). California: Stanford University Press.

Bretthauer, B., Zimmerman, T. S., \& Banning, J. H. (2007). A Feminist Analysis of Popular Music. Journal of Feminist Family Therapy, 18(4), 2951.

https://doi.org/10.1300/J086v18n04_02

Dayanti, L. D. (2006). Potret Kekerasan Gender dalam Sinetron Komedi di Televisi. Jurnal Masyarakat, Kebudayaan Dan Politik, 19(3).

Dwizatmiko. (2010). Kuasa Simbolik Menurut Pierre Bourdie; Telaah Filosofis. Ubiversitas Indonesia.

Eriyanto. (2001). Analisis Wacana: Pengantar Analisis Teks Media. Yogyakarta: LKiS.

Gamble, S. (2001). The Routledge Companion to Feminism and Postfeminism. London: Routledge.

Hamid, Farid dan Budianto, H. (2011). Ilmu Komunikasi: Sekarang dan Tantangan Masa Depan. Jakarta: kencana.

Hannam, J. (2007). Feminism. Harlow England.: Pearson-Longman.

Haryatmoko. (2010). Dominasi Penuh Muslihat; Akar Kekerasan dan Diskriminasi. Jakarta: Gramedia.

Hassan, A. (2018). Language, Media, and Ideology: Critical Discourse Analysis of Pakistani News Bulletin Headlines and Its Impact on Viewers. SAGE Open, $\quad 8(3), \quad 2158244018792612$. https://doi.org/10.1177/2158244018792 612
Heitmeyer, Wilhelm dan Hagan, J. (2005). International Handbook of Violence Research. Dordrecht: Kluwer Academic.

Hidayat, A. (2012). BAHASA DAN HEGEMONI KEKUASAAN (Telaah atas Kekerasan Simbolik di dalam Media). JURNAL KARSA (Terakreditasi No. 80/DIKTI/Kep/2012), (Vol 9, No 1 (2006): Islam dan Wacana Radikalisme), 871 â $\square$ “ 883. Retrieved from http://karsa.stainpamekasan.ac.id/index. php/jks/article/view/119

Murniati, A. N. (2004). Getar Gender. Magelang: Indonesia Tera.

Mustakim, A. G. (2012). Representasi Perempuan Dalam Kanji (Analisis Semiotika Terhadap Buku Kanju Pictographix). Universitas Indonesia r.

Nurgiyantoro, B. (2010). Teori Pengkajian Fiksi. Yogyakarta: Universitas Gajah Mada.

Rakoczy, S. (2004). Religion and violence: the suffering of women. Agenda, $18(61)$, 29-35. https://doi.org/10.1080/10130950.2004. 9676037

Recuero, R. (2015). Social Media and Symbolic Violence. Social Media + Society, 1(1), 2056305115580332. https://doi.org/10.1177/2056305115580 332

Ritzer, George dan Goodman, D. J. (2003). Teori Sosiologi Modern. Jakarta: Prenada Media.

Rohimi, P. (2012). Tokoh Perempuan dalam Film: Studi tentang Representasi Tokoh Perempuan dalam Film Indonesia Bertema Islam Tahun 19802010. IAIN Walisongo.

Siregar, A. (2004). Ketidakadilan Konstruksi Perempuan di Film dan Televisi. Jurnal 
IlmuSosial Dan Ilmu Politik UGM Yogyakarta, 7(3).

Sobari, T. (2011). Kekerasan Simbolik Dalam Bahasa Lirik Lagu. Jurnal @artikulasi, 10(1). Retrieved from http://jurnal.upi.edu/artikulasi/view/883 /kekerasan-simbolik-dalam-bahasalirik-lagu.html

Sunarto. (2000). Analisis Wacana Ideologi Gender Media Anak-anak. Semarang: Mimbar dan Yayasan Aikary Alkapi serta Ford Foundation.

Udasmoro, W. (2013). Symbolic Violence In Everyday Narrations: Gender Construction In Indonesian Television. Jurnal Asian Journal of Social Sciences \& Humanities, 2(3).

Wittebols, J. H. (2004). The soap opera paradigm: television programming and corporate priorities. Rowman \& Littlefield Publishers. 